\title{
Lexical Interference and Ways of Its Elimination: Based on Experience with Junior Course Students of the Azerbaijan University of Languages
}

\author{
Kamala Avadır Jafarova ${ }^{1}$ \\ ${ }^{1}$ School of Humanities, Department of Languages, Baku Business University (BBU), Azerbaijan \\ Correspondence: Kamala Avadır Jafarova, School of Humanities, Department of Languages, Baku Business \\ University (BBU), Azerbaijan. E-mail: kamacafarova_adu@mail.ru
}

Received: January 20, 2020 Accepted: February 25, 2020 Online Published: March 1, 2020

doi:10.5539/ijel.v10n2p392 URL: https://doi.org/10.5539/ijel.v10n2p392

\begin{abstract}
The problem of language interference being a process which retards the mastering of a second language, having appeared as a result of transference of speech skills from one contact language into another (from the native language into the foreign language, from the first foreign language into the second one), has concerned researchers for decades. This phenomenon has a direct influence on the success of an individual's mastery of a foreign language and its use - involving both receptive and productive types of speech activities.

Interference resulting from the negative impact of one language on another covers all linguistic levels of the language being studied, including lexical, which leads to deviations from the language norm and numerous lexical errors of students. Linguists and methodologists are trying to find ways to reduce the interference of the language being studied at the lexical level in order to optimize the process of mastering a foreign language and minimize lexical errors of students. The purpose of the current study is to investigate ways to overcome intra-language and inter-language lexical interference in junior courses of the Azerbaijan University of Languages and to verify the validity of these methods in the course of a practical experiment.
\end{abstract}

Keywords: diaparonyms, elimination, inter-language interference, intra-language interference, lexical interference

\section{Introduction}

There are a large number of approaches to classifying types of interference, but taking the source of appearance of interference into consideration, two main types of interference can be distinguished: "interference of the native language and interference of a foreign language" or "inter-language (external) interference" and "intra-language (internal) interference". Within each of these distinguished types, there may be different varieties depending on the nature of the interacting system on the conditions existing in language contacts, etc. (Kazimirova, 2006).

Inter-language interference is considered by the investigators as one of the most powerful factors of the negative influence of the native language on the studied language, as the practice of teaching shows that the majority of existing mistakes are those mistakes which are caused by the interfering influence of the system of the native language, having taken its roots in the consciousness of the learners. It should be noted here that when students learn two foreign languages, the foreign language they previously learned will also have a negative impact on the foreign language they later learn. Consequently, inter-language interference also occurs here (Kazimirova, 2006).

It should be noted that the influence of inter-language interference is greatest at the initial stage of learning a foreign language, while the influence of intra-language interference is typical for both the initial and advanced stages of learning a foreign language.

Inter-language interference is manifested either in the illegal transfer of phenomena of the native or previously studied languages to the foreign language being studied later and the formation of incorrect, non-existent phenomena in the foreign (later studied) language, or in the non-use of phenomena of the second foreign language due to their absence in the native or first foreign language. This interference can manifest itself both at the level of form and at the level of meaning and act at all levels of the language system: phonological, lexical, 
and grammatical (Kazimirova, 2006).

A striking example of inter-language interference is the phrase of a Russian-speaking customer who, after making his choice at the store counter, addresses the seller with the words: "To me that please". This phrase is incorrect not only from the grammatical point of view (the absence of any verb), but also from the socio-cultural point of view. Even a grammatically correct sentence "Please give me this" for an English-speaking seller will sound very unnatural and may even be considered rude. In this case, it would have been better to say, "Can I have this?/Can you show me this one, please", but the buyer, building his statement, was influenced by the native language, taking into account only its rules and regulations (Kazimirova, 2006).

In contrast to inter-language, intra-language interference is observed within the framework of the studied language and manifests itself in the displacement of less mastered or less frequent phenomena of the foreign language being studied by more learned or more frequent phenomena (Kazimirova, 2006).

\section{Literary Review}

\subsection{Interference}

The term "interference" comes from the Latin words "inter" (between) and "ferens"/"ferentis" (carrier, transfering) (Adamchik, 2006). It first appeared in the field of physics, chemistry, and biology, and then was borrowed into the field of linguistics. This phenomenon is studied in linguistics, psychology, and psycholinguistics, etc. and can manifest itself in both oral and written speech.

In linguistics, the problem of interference is considered within the framework of language contacts and interference is understood as a violation by a bilingual (a person who speaks two languages) of the norms and rules of the relationship between two contacting languages (Alimov, 2005).

Psychologists consider interference as the occurrence of obstacles and hindrances due to the transfer of skills and abilities from one activity to another.

Taking into account the psycholinguistic side of this phenomenon, as the form of speech products caused by interference is due to the functioning of psycho-physiological mechanisms of their appearance; then interference must be considered as a process of conflict interaction of speech mechanisms caused by objective discrepancies, which is externally manifested in bilingual speech in deviations from the laws of one language under the influence of negative interaction of another or due to intra-linguistic influences of a similar nature (Sorokina, 1971).

\subsection{Overcoming Interference}

Lugovets emphasizes the fact that in order to overcome the negative impact of inter-lingual lexical interference, it is necessary to periodically analyze the lexical units of the native and studied languages. Comparative analysis helps to identify lexical phenomena that pose the greatest difficulties for students. The selection of texts and exercises, as well as the preparation of test papers which take into account the possibility of inter-language lexical interference is one of the important elements of organizing effective training. Taking into account the possibility of lexical interference when learning a foreign language, teachers can prevent some mistakes of students, reduce their number and, thus, facilitate the learning process (Lugovets, 2016).

Aliyeva also argues that in order to overcome inter-language lexical interference, it is necessary to identify similarities and differences in the lexical structure of the native and studied foreign languages and determine "inter-language equivalents". In addition, it is recommended to use inter-language exercises for comparison and contrast in order to familiarize students with the existing difficulties (Aliyeva, 2012).

\section{Research Methodology}

The main purpose of the present study is to investigate overcoming the intra-language and inter-language lexical interference for junior courses of the Azerbaijan University of Languages. It seemed appropriate to divide specially designed exercises into three main stages:

1) establishing the presence of interfering effects on the students;

2) students do exercises aimed at overcoming this impact;

3) final testing of the students, allowing the tracing of changes in the level of interfering impacts in comparison to the initial stage.

The purpose of the first stage of work on overcoming intra-language and inter-language lexical interference was to establish the presence of an interfering influence in students, assess its degree, and identify the source of lexical interference in each individual case. To do this, students were asked to perform the following exercises: 
- Match the suggested English words with their Azerbaijani equivalents;

- Translate the sentences into English;

- Circle the correct answer in brackets etc.

The purpose of the second and third stages of the work was to identify ways to overcome lexical interference at the intra-language and inter-language levels, conduct experimental testing among junior course students, and develop 17 exercises aimed at overcoming inter-language and intra-language lexical interference caused by various factors, and include exactly those lexical units that caused many lexical errors of junior course students. These exercises implemented the principles that are considered the most effective in reducing interference in the field of lexes both at the inter-lingual and intra-linguistic levels, (the principles of inter-lingual contrastive and comparative analysis, the principle of visual clarity, the principle of using semantic context, the use of self-control mechanisms, etc.).

In all three stages of the research work, the students were given 17 exercises to perform. However, not all the exercises are presented in this article- just some of them are described.

\subsection{Participants}

This linguistic experiment was attended by 20 first-year students at the faculty of Education of the Azerbaijan University of Languages. Students were forbidden to use any kind of dictionaries or reference materials during the exercises, to ensure the "purity" of the experiment: to identify the true level of proficiency in the presented lexical units and to determine the areas of interference. When analyzing the exercises performed by students, grammatical, spelling, and other errors that are not related to the phenomenon of lexical interference were not taken into account.

\section{Results, Data, Analysis and Discussions}

Examples of inter-language contrasting exercises (exercises that implement the principle of comparing lexical units of English and lexical units of the Azerbaijani language) are the following:

\section{Exercise 1. Match the suggested English words with their Azerbaijani equivalents, choosing one of these} three options.

\section{1) Academic}

a) dərs saatı

b) praktik əhəmiyyət kəsb etməyən, yalnız nəzəri maraq

c) bir kollecdə və ya ali təhsil müəssisəsində müəllim və ya alim

\section{2) Argument}

a) arqument

b) sübut/dəlil

c) mübahisə

\section{3) Cabinet}

a) məqalələrin saxlanması və ya göstərilməsi üçün çekmece və ya rəflər olan bir şkaf

b) cabinet (şəxsi iş otagi)

c) (ABŞ-da) hökumətin icra şöbələrinin rəhbərlərindən ibarət prezidentin müşavirlər qrupu

\section{4) Bank}
a) bank
b) çay kənarı
c) qiraq/kənar

\section{5) Caravan}
a) karvan
b) nəqliyyat vasitəsi
c) süvari 


\section{6) Tort}

a) tort

b) qanunsuz hərəkət/qanun pozuntusu

c) əzab

7) Mayor

a) mayor

b) bələdiyyə başçısı

c) şəhərin meri

\section{8) Designer}
a) dizayner
b) konstruktor
c) tərtibatç1

\section{Exercise 2. Translate the sentences into English.}

- Biz stansiyaya çatanda hava qaralmışdı.

- Məni nənəm və babam böyüdüb.

- Mən iş üçün müraciət etməyi qərara aldım.

- O, məni axmaq adlandıranda, həqiqətən, duyğularımı yaraladı.

- Mən həqiqəti ona deməməklə böyük bir səhv etdim.

\section{Exercise 3. Circle the correct answer in brackets.}

1) Everything is arranged (accept/except/expect) for the tickets to the theatre

(http://www.common-language.ru).

2) I've chosen the sea (shore/coast/bank) as the final resting place for my little beauty.

(http://sentence.your dictionary.com/seashore).

3) In autumn most trees are (bare/bear/bair).

(http://selfstudymaterials.com 1000-english-collocations-10-minutes-day-pdf)

4) She (did/made) a squeaking noise and fainted.

( http://selfstudymaterials.com 1000-english-collocations-10-minutes-day-pdf)

5) Tom was jealous (for/about/of) Jane, so he accused her (of/in/with) unfaithfulness.

(http://selfstudymaterials.com 1000-english-collocations-10-minutes-day-pdf)

The exercises of this type work as a "simulator" for undergraduate students, because if they repeatedly refer to a foreign language lexical item that can cause interference, the student will habitually use a dictionary or other source in order to find the true semantic meaning of the lexical items (Lugovets, 2016).

The exercises, which take into account the principle of comparison of lexical language units of native and studied languages, can be effectively used in the "struggle" with the "false friends of the translator" as the source of inter-lingual lexical interference.

However, varieties of exercises aimed at overcoming lexical interference caused by the polysemy of words or the differences within the norms of lexical combinability of two languages, as well as intra-language exercises for the comparison of vocabulary of the English language (when working with synonymy, antonymy, homonymy, and paronymy) are possible.

An analysis of interfering vocabulary should explain the nature of the studied vocabulary (Abdygaliev, 1976). Therefore, an effective process of revealing the meaning of a lexical unit-its semantics — can be considered as one of the ways to prevent lexical interference. There are many ways of semantization of language units in the methodology of teaching foreign languages, and choosing the most appropriate and "memorable" one can significantly reduce the risk of further lexical interference among students (Lugovets, 2016).

The choice of the method of semantization in each individual case is determined by the nature of the language unit, by 
the stage of training and the level of training of students. These methods are divided into monolingual and transferred ones. Monolingual methods in which the meaning of a word is disclosed in the foreign language being studied include: contextualization, presentation of a definition, use of visual aids, presentation of synonyms or antonyms of a unit, and usage of word-forming elements (Lugovets, 2016).

It is considered that to explain the meaning of lexical units that are potentially subject to interference, it is preferable to choose such methods of semantics as contextualization and the use of visual tools (Aliyeva, 2012). It is assumed that after getting acquainted with a new lexical unit in a sufficient and understandable context, realizing the meaning of this word independently with the help of a language-aided guess, the student will remember it better, and the probability of receptive and productive lexical interference will be minimized (Aliyeva, 2012).

One of the ways to "fight" lexical interference, according to some scientists, is to use self-control mechanisms, which involves the analysis of the students' own lexical errors caused by the phenomenon of inter-language or intra-language interference, and the assessment of the value of the influence of this error on the process of studying a foreign language. Conscious analysis and correction of their own lexical errors, rather than a simple "mechanical" correction by the teacher, will help to fix in the memory of a student the features of particular language units, which will help to overcome interference. Self-control will also contribute to the development of students' critical thinking (Lugovets, 2016).

Many methodologists also believe that in order to prevent and overcome lexical interference, it is necessary to deliberately draw the attention of students (especially junior students) to potentially interfering vocabulary (Yanchenko, 2012).

For this, reason Tedtoeva suggests introducing students to the phenomenon of "false friends of the translator" with the help of a special glossary, which should contain English language units which most often cause false associations in students of junior courses, and their translation into the students' native language (Tedtoeva, 2016).

\subsection{Detection of Interfering Effects}

In the above-mentioned first assignment lexical units were presented, included as diaparonyms or "false friends of the translator" ("academic", "argument", “cabinet", "bank", "caravan", "tort", “mayor", "designer"), and the students were instructed to match English words with their Azerbaijani equivalents. This exercise allowed us to assess the level of inter-lingual lexical interference associated with the phenomenon of diaparonyms. Potential lexical errors were: "academic" - "akademik", "argument" - "arqument", "cabinet" - "kabinet", "bank" "bank", "caravan" - "karvan", "tort" - "tort", "mayor" - "mayor", "designer" - “dizayner".

We received the following results when analyzing the submitted task performed by 20 students. The results are presented in Table 1.

Table 1. Indication of the level of inter-language lexical interference

\begin{tabular}{|c|c|c|c|}
\hline Presented words & Azerbaijani equivalents & N/S-20 & Lexical errors \% \\
\hline 1. Academic & $\begin{array}{l}\text { a) dərs saat1 } \\
\text { b) praktik əhəmiyyət kəsb etməyən, yalnız nəzəri maraq } \\
\text { c) bir kollecdə və ya ali təhsil müəssisəsində müəllim və ya alim }\end{array}$ & 17 & $85 \%$ \\
\hline 2. Argument & $\begin{array}{l}\text { a) arqument } \\
\text { b) sübut/dəlil } \\
\text { c) mübahisə }\end{array}$ & 12 & $60 \%$ \\
\hline 3. Cabinet & $\begin{array}{l}\text { a) məqalələrin saxlanması və ya göstərilməsi üçün çekmece və ya rəflər olan } \\
\text { bir şkaf } \\
\text { b) cabinet (şəxsi iş otagı) } \\
\text { c) (ABŞ-da) hökumətin icra şöbələrinin rəhbərlərindən ibarət prezidentin } \\
\text { müşavirlər qrupu }\end{array}$ & 10 & $50 \%$ \\
\hline 4. Bank & $\begin{array}{l}\text { a) bank } \\
\text { b) çay kənarı } \\
\text { c) quraq/kənar }\end{array}$ & 8 & $40 \%$ \\
\hline 5. Caravan & $\begin{array}{l}\text { a) karvan } \\
\text { b) nəqliyyat vasitəsi } \\
\text { c) süvari }\end{array}$ & 16 & $80 \%$ \\
\hline 6. Tort & $\begin{array}{l}\text { a) tort } \\
\text { b) qanunsuz hərəkət/qanun pozuntusu } \\
\text { c) əzab }\end{array}$ & 15 & $75 \%$ \\
\hline 7. Mayor & $\begin{array}{l}\text { a) mayor } \\
\text { b) bələdiyyə başçısı } \\
\text { c) şəhərin meri }\end{array}$ & 14 & $70 \%$ \\
\hline 8. Designer & $\begin{array}{l}\text { a) dizayner } \\
\text { b) konstruktor } \\
\text { c) tərtibatçı }\end{array}$ & 15 & $75 \%$ \\
\hline
\end{tabular}


Thus, the average number of incorrect answers given by the tested students in one or another case is $66 \%$, which means that the level of interfering influence of the Azerbaijani language in the field of vocabulary (the level of inter-language lexical interference associated with the phenomenon of "false friends of the translator") is $65 \%$. This leads to the conclusion that the phenomenon of diaparonymy is quite difficult for students of junior courses of language Universities and is a vast field for lexical errors caused by interference, which in turn indicates the need to pay special attention to the "false friends of the translator" and the expediency of performing specially designed exercises.

The second translation exercise was aimed at identifying the degree of inter-language lexical interference associated with the "transfer" of lexical combinability norms from the native language to the foreign language being studied. Possible lexical errors under the influence of interference here could be: " ... we arrived on the station" (instead of ... we arrived at the station); "I was raised ..." (instead of I was rose ...); " ... apply for the work" (instead of ... apply for the job); “ ... hurt my emotions" (instead of ... hurt my feelings); “ ... saying her the truth" (instead of ... telling her the truth). As for the last example " ... saying her the truth" lexical errors in this case can also be associated with the intra-linguistic influence of English, and with the mixed influence of both, so the source of interference is quite difficult to determine here.

However, the last sentence ("Mən haqiqati ona deməməkla böyük bir sahv etdim" - "I made a big mistake by not telling her the truth") could "provoke" errors caused not by inter-language interference, but also by mixed lexical interference: at first, the wrong choice of words from the synonymic rows, which is often associated with the phenomenon in terms of the differentiated values in the lexicon of the native language compared to English ("demək" - "say/tell", "etmək" - "make/do"); secondly, it is associated a great deal with "assimilation" of one lexical unit in comparison with another. Thus, potential errors here could be: "I did a mistake" and "I didn't say the truth". It is worth noting that these errors, whatever their source might be, in any case lead to a violation of the norms of lexical combinability in the foreign language.

When analyzing the translation performed by students, it was found that the norms of lexical combinability of the English language under the influence of both inter-language and intra-language interfering factors were violated in the following cases. The results were presented in Table 2.

Table 2. Indication of the students' lexical errors

\begin{tabular}{|c|c|c|c|c|}
\hline Presented sentences & Examples of errors & Corrections & N/S-20 & $\begin{array}{l}\text { Lexical } \\
\text { errors } \%\end{array}$ \\
\hline $\begin{array}{l}\text { 1. Biz stansiyaya çatanda hava } \\
\text { qaralmışdı. }\end{array}$ & $\begin{array}{l}\text { It was dark by the time we } \\
\text { arrived on the station. }\end{array}$ & $\begin{array}{l}\text { It was dark by the time we } \\
\text { arrived at the station. }\end{array}$ & 13 & $65 \%$ \\
\hline 2. Məni nənəm və babam böyüdüb. & I was rose by my grand- parents. & $\begin{array}{l}\text { I was raised by my } \\
\text { grandparents. }\end{array}$ & 9 & $45 \%$ \\
\hline $\begin{array}{l}\text { 3. Mən iş üçün müraciət etməyi } \\
\text { qərara aldım. }\end{array}$ & I decided to apply for the work. & I decided to apply for the job. & 10 & $50 \%$ \\
\hline $\begin{array}{l}\text { 4. O, məni axmaq adlandıranda, } \\
\text { həqiqətən, hisslərimlə oynadı. }\end{array}$ & $\begin{array}{l}\text { He really hurt my emotions when } \\
\text { he called me an idiot. }\end{array}$ & $\begin{array}{l}\text { He really hurt my feelings } \\
\text { when he called me an idiot. }\end{array}$ & 12 & $60 \%$ \\
\hline $\begin{array}{l}\text { 5. Mən həqiqəti ona deməməklə } \\
\text { böyük bir səhv etdim. }\end{array}$ & $\begin{array}{l}\text { I made a big mistake not saying } \\
\text { her the truth. }\end{array}$ & $\begin{array}{l}\text { I made a big mistake not } \\
\text { telling her the truth. }\end{array}$ & 8 & $40 \%$ \\
\hline
\end{tabular}

Note. Sentences in which the sources are not mentioned belong to the author.

So, the average number of incorrect answers given by the tested students in the given exercise is $52 \%$, which means that the level of lexical interference associated with the" transfer" of lexical combinability norms from Azerbaijani into English, as well as intra-language factors, is $52 \%$. This suggests that first-year students of a language University have a fairly good command of the norms of lexical combinability of the English language, but the interfering effect can and should be minimized in order to avoid lexical errors.

The third exercise which was presented to the learners involved choosing the only correct variant from two or three presented options. The first sentence in it aimed to identify the intra-language lexical interference caused by the phenomenon of paronymy of the English language ("accept/except/expect", where "except" is the only correct option); the second is mixed lexical interference, which leads to violation of the norms of lexical combinability in the Foreign Language when choosing the wrong variant ("sea shore" is the only correct variant because the lexical units "bank" and "coast" are used when it comes to the bank of a river or ocean); the third is intra-language lexical interference related to the phenomenon of homonymy of the English language (the 
existence of homophones such as "bare", "bear" and "bair", the first of which in this case will be the correct variant-" "bare trees"). The fourth and fifth sentences, as well as the second, were aimed at determining the "transfer" of lexical norms from native language to a foreign language by students, but some intra-language factors could also influence the choice of the wrong variant ("made a noise", "jealous of" and "accused of" are the only correct variants here).

The received results were presented in Table 3 given below.

Table 3. Indications for violation of the norms of lexical combinability

\begin{tabular}{|c|c|c|}
\hline Examples of errors & $\mathbf{N} / \mathbf{S}-\mathbf{2 0}$ & Lexical errors \% \\
\hline 1. Everything is arranged (accept/except/expect) for the tickets to the theatre & 6 & $30 \%$ \\
\hline 2. I've chosen the sea (shore/coast/bank) as the final resting place for my little beauty. & 17 & $85 \%$ \\
\hline 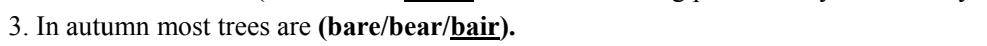 & 4 & $20 \%$ \\
\hline 4. She (did/made) a squeaking noise and fainted. & 13 & $65 \%$ \\
\hline 5. Tom was jealous (for/about/of) Jane, so he accused her (of/in/with) unfaithfulness. & 18 & $90 \%$ \\
\hline
\end{tabular}

When analyzing the results, it was counted that the level of lexical interference associated with the phenomenon of paronymy of the English language is 30\% (6 students out of 20 answered incorrectly); with the phenomenon of homonymy of the English language is $20 \%$ (4 students out of 20 answered incorrectly); 20 students in total made 48 errors in the second, fourth and fifth sentences, which means the level of lexical interference associated with the "transference" of lexical norms from one language into another is on average $50 \%$.

\subsubsection{Result}

Summing up the results of the testing, we can conclude that the degree of lexical interference detected in students of junior courses of a language university is quite high, which leads to numerous lexical errors of students. This testing also helped to conclude that inter-language factors in the study of a foreign language have a greater impact on undergraduate students than intra-language ones: the degree of inter-language interference (about $75 \%$ of all erroneous responses) was much higher than intra-language interference (about $25 \%$ of all erroneous responses).

We also concluded that diaparonyms or "false friends of the translator" are the most difficult for junior students, because they are the lexical units that are most susceptible to interference from the Azerbaijani language; followed by the norms of lexical combinability of English and their "transference" from the Azerbaijani language (lexical interference); the least difficulties were caused by the phenomena of paronymy and homonymy of the English language: lexical interference with these was low.

The percentage of language phenomena that caused lexical interference during testing is shown in Figure 1.

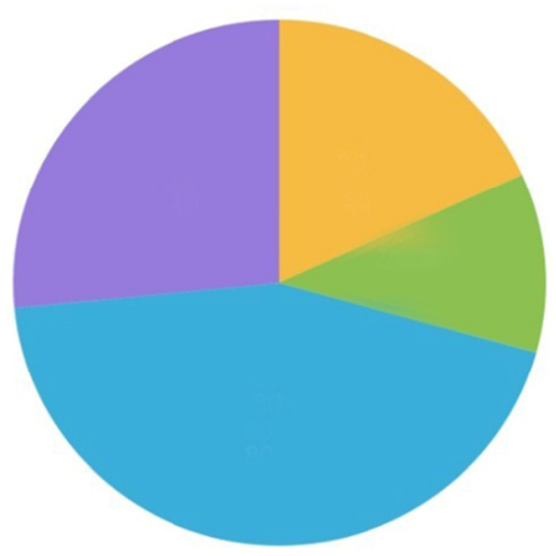

Diaparonymy $40 \%$

\section{Lexical combinability $35 \%$}

Paronymy $15 \%$

Homonymy $10 \%$

Figure 1. Correlation of language phenomena that caused interference

So, we are assured about the necessity and purposefulness of working out exercises directed to the liquidation of interferences which the students of junior classes possess. The findings also acted to confirm the percentage relations 
of language phenomena and sources of lexical interference, as well as led to the discovery of facts which demand particular attention.

\subsection{Overcoming of Interfering Effects}

So, as the test results showed, most of the difficulties for junior students and the highest level of interference were caused by the phenomenon of "false friends of the translator". Just to overcome lexical interference associated with the phenomenon of diaparonymy, the following exercises are purposeful.

As we see that lexical errors of this type are always caused by inter-language factors, it seemed appropriate to develop an inter-language contrasting exercise, as well as an exercise based on the principle of inter-language comparison:

Exercise 1. Discuss with your classmates the differences between Azerbaijani and English words. Give English equivalents to the Azerbaijani words and Azerbaijani equivalents to the English words. Make up sentences using each of these words.

academic - akademik

argument - arqument

cabinet - kabinet

bank - bank

caravan - karvan

tort - tort

mayor - mayor

designer - dizayner

Note: The words and phrases given in the assignments at this stage are the same as the words and phrases in the previous stage. But the condition of the given tasks is different. Our goal is to reveal how the lexical units exposed to interference are strengthened in the memory of students at the first stage.

As can be seen from the introduced exercise, the lexical units that caused difficulties among the students during the initial testing were listed. When performing this and the following exercises developed by us, unlike the previous stage, the students were allowed to use any kind of dictionaries and reference resources. This exercise involved the use of dictionaries and reference books in pairs and the search for Azerbaijani and English equivalents to the specified language units, also carried out by them in pairs, checking up and discussing what was done together with the teacher, drawing up proposals individually with subsequent verification. It is also a good idea for students to make up questions of various types with these "false friends of the translator" for their classmate and speak in pairs/groups in order to find out such problematic lexical units in speech, which will ensure their better assimilation and consolidation.

As for the interference associated with the transfer of norms of lexical combinability from the Azerbaijani language into English (incorrect choice of a synonym from familiar variants under the influence of the native language, the use of incorrect verb/adjective control under the influence of the native language), the following language exercises were developed:

\section{Exercise 2. Translate the following phrases into English.}

stansiyaya çatmaq, boya-başa çatdırılmaq, iş üçün müraciət etmək, hissləri ilə oynamaq, səhv etmək.

\section{Exercise 3. Underline the correct option.}

1) We decided not to (accept/except/expect) her invitation.

2) Everybody was invited to the party (accept/except/expect) Jane.

3) I didn't (accept/except/expect) you so late.

1) Baku is located on the (shore/coast/bank) of the Caspian Sea.

2) It says it's an island off the (shore/coast/bank) of Ireland.

(https://sentence.yourdictionary.com/coast)

3) Our village is situated near the river (shore/coast/bank).

1) A (bare/bear/bair) is a huge animal found in a wide variety of habitats. 
2) In autumn leaves fall off and most trees get (bair/bear/bare).

3) A (bare/bear/bair) is food or other lure placed on a hook or in a trap and used in the taking of fish, birds or other animals.

1) We (did/made) not go to the party yesterday.

2) Why do you always (did/made) the same mistake?

1) She doesn't have any reason to be jealous (for/about/of) me.

(https://sentence.yourdictionary.com/jealous)

2) In Hungary, as in Italy, he was accused (of/in/with) brutality.

(https://sentence.yourdictionary.com/accused)

Exercises that help overcome interference, accompanied by the "transference" of lexical combinability norms from Azerbaijani into the English language, may also have a different character, but the order of their presentation to students should be logical: starting from tasks for multiple choice, substitution, opening brackets, moving on to the analysis of errors in the text, their correction, and ending with the actual translation exercises (phrases, and then whole sentences).

After performing such lexical exercises and development of a plan of the necessary language units together with the teacher, work on the exercises directed to the language materials for the better consolidation of interfering lexes is also recommended. These can be exercises for using the given language units both in written speeches (forming of sentences/texts with them) and in oral speech (interviewing classmates with questions, composed in relation to the given lexical units). The output of language material in speech (written or oral) will contribute to its assimilation.

These exercises were offered to the same group of 20 first-year students who performed the initial testing. As noted above, students had the right to use any type of dictionaries and reference resources when performing exercises and, if necessary, to work in pairs/groups, if the task required it.

When analyzing the tasks performed by students, it was found that the vast majority of them could do their exercises successfully: in the works of 20 students, totally 3 errors were found out of 120 possible ones, which means that $99 \%$ of the students performed the presented exercises correctly. Errors may have been caused by inattention or non-use of reference materials.

We have made the assumption that if you repeatedly refer to dictionaries/reference books, problematic lexical units will firmly entrench in the memory of students (the same lexes are found in various types of exercises and constantly "remind you of yourself").

\subsubsection{The Analysis of the Dynamics of Interfering Effects}

At the third and final stage of work on overcoming intra-language and inter-language lexical interference among the students of junior courses, students were offered to perform exercises that were used to identify interfering effects during the initial testing.

This stage of the work aimed to track the dynamics of this impact: to determine the level of lexical interference of students after they performed specially designed exercises and compare it with the original one, helped to draw a conclusion about the feasibility and necessity of developing such exercises in the future. At the final testing stage, as it was mentioned, students were forbidden to use any type of dictionaries and reference resources in order to ensure the "purity" of the experiment: to identify the true level of proficiency in the presented lexical units. Grammar, spelling, and other errors not related to the phenomenon of lexical interference were not taken into account when checking the exercises performed by students.

After re-analyzing the first exercise performed by the students, the following results were received. The results are presented in Table 4. 
Table 4. Indication of the level of inter-language lexical interference after re-analysis

\begin{tabular}{|c|c|c|c|}
\hline Presented words & Azerbaijani equivalents & $\mathbf{N} / \mathbf{S}-\mathbf{2 0}$ & $\begin{array}{l}\text { Lexical } \\
\text { errors \% }\end{array}$ \\
\hline 1. Academic & $\begin{array}{l}\text { a) dərs saatı } \\
\text { b) praktik əhəmiyyət kəsb etməyən, yalnız nəzəri maraq } \\
\text { c) bir kollecdə və ya ali təhsil müəssisəsində müəllim və ya alim }\end{array}$ & 4 & $20 \%$ \\
\hline 2. Argument & $\begin{array}{l}\text { a) arqument } \\
\text { b) sübut/dəlil } \\
\text { c) mübahisə }\end{array}$ & 3 & $15 \%$ \\
\hline 3. Cabinet & $\begin{array}{l}\text { a) məqalələrin saxlanması və ya göstərilməsi üçün çekmece və ya rəflər olan bir şkaf } \\
\text { b) cabinet (şəxsi iş otagı) } \\
\text { c) (ABŞ-da) hökumətin icra şöbələrinin rəhbərlərindən ibarət prezidentin müşavirlər } \\
\text { qrupu }\end{array}$ & 2 & $10 \%$ \\
\hline 4. Bank & $\begin{array}{l}\text { a) bank } \\
\text { b) çay kənarı } \\
\text { c) qriraq/kənar }\end{array}$ & 1 & $5 \%$ \\
\hline 5. Caravan & $\begin{array}{l}\text { a) karvan } \\
\text { b) nəqliyyat vasitəsi } \\
\text { c) süvari }\end{array}$ & 0 & $0 \%$ \\
\hline 6. Tort & $\begin{array}{l}\text { a) tort } \\
\text { b) qanunsuz hərəkət/qanun pozuntusu } \\
\text { c) əzab }\end{array}$ & 3 & $15 \%$ \\
\hline 7. Mayor & $\begin{array}{l}\text { a) mayor } \\
\text { b) bələdiyyə başçısı } \\
\text { c) şəhərin meri }\end{array}$ & 2 & $10 \%$ \\
\hline 8. Designer & $\begin{array}{l}\text { a) dizayner } \\
\text { b) konstruktor } \\
\text { c) tərtibatçı }\end{array}$ & 4 & $20 \%$ \\
\hline
\end{tabular}

Thus, the average number of incorrect answers given by the tested students in one or more cases is $13 \%$, which means that the level of interfering influence of the Azerbaijani language in the field of vocabulary (the level of inter-language lexical interference associated with the phenomenon of "false friends of the translator") is $13 \%$ in comparison with the origin which is $66 \%$. This indicator identifies a significant decrease in the interfering effect of the students in this field, and a better assimilation of the presented language units compared to the initial one. When re-analyzing the second exercise performed by students, it was found that the norms of lexical combinability of the English language under the influence of both inter-language and intra-language interfering factors were violated in the following cases. The results are presented in Table 5.

Table 5. Indication of the students' lexical errors after re-analysis

\begin{tabular}{|c|c|c|c|c|}
\hline Presented sentences & Examples of errors & Corrections & $\mathbf{N} / \mathbf{S}-\mathbf{2 0}$ & $\begin{array}{l}\text { Lexical } \\
\text { errors \% }\end{array}$ \\
\hline $\begin{array}{l}\text { 1. Biz stansiyaya çatanda hava } \\
\text { qaralmışdı. }\end{array}$ & $\begin{array}{l}\text { It was dark by the time we } \\
\text { arrived on the station. }\end{array}$ & $\begin{array}{l}\text { It was dark by the time we } \\
\text { arrived at the station. }\end{array}$ & 2 & $10 \%$ \\
\hline 2. Məni nənəm və babam böyüdüb. & $\begin{array}{l}\text { I was } \underline{\text { rose }} \text { by my grand- } \\
\text { parents. }\end{array}$ & $\begin{array}{l}\text { I was raised by my } \\
\text { grandparents. }\end{array}$ & 2 & $10 \%$ \\
\hline $\begin{array}{l}\text { 3. Mən iş üçün müraciət etməyi } \\
\text { qərara aldım. }\end{array}$ & I decided to apply for the work. & $\begin{array}{l}\text { I decided to apply for the } \\
\text { job. }\end{array}$ & 3 & $15 \%$ \\
\hline $\begin{array}{l}\text { 4. O, məni axmaq adlandıranda, } \\
\text { həqiqətən, hisslərimlə oynadı. }\end{array}$ & $\begin{array}{l}\text { He really hurt my emotions } \\
\text { when he called me an idiot. }\end{array}$ & $\begin{array}{l}\text { He really hurt my feelings } \\
\text { when he called me an idiot. }\end{array}$ & 2 & $10 \%$ \\
\hline $\begin{array}{l}\text { 5. Mən həqiqəti ona deməməklə } \\
\text { böyük bir səhv etdim. }\end{array}$ & $\begin{array}{l}\text { I made a big mistake not } \\
\text { saying her the truth. }\end{array}$ & $\begin{array}{l}\text { I made a big mistake not } \\
\text { telling her the truth. }\end{array}$ & 0 & $0 \%$ \\
\hline
\end{tabular}

So, the average number of incorrect answers given by the tested students in the performed exercise is $11 \%$, which means that the level of lexical interference associated with the "transfer" of lexical combinability norms from Azerbaijani into the English language, as well as intra-language factors, is $11 \%$ compared to the original $52 \%$. This indicates a decrease in the level of lexical interference after students perform specially designed exercises and work on "problematic" vocabulary. 
When re-analyzing the third exercise, which involved students choosing one correct variant from two or three presented options, the following results were received. The results are presented in Table 6 .

Table 6. Indications for violation of the norms of lexical combinability after re-analysis

\begin{tabular}{lll}
\hline Presented sentences & N/S-20 & Lexical errors \% \\
\hline 1. We decided not to (accept/except/expect) her invitation. & 2 & $10 \%$ \\
2. Everybody was invited to the party (accept/except/expect) Jane. & \\
3. I didn't (accept/except/expect) you so late. & 3 & $15 \%$ \\
1. Baku is located on the (shore/coast/bank) of the Caspian Sea. & \\
2. It says it's an island off the (shore/coast/bank) of Ireland. & \\
3. Our village is situated near the river (shore/coast/bank). & $\mathbf{3} \%$ \\
1. A (bare/bear/bair) is a huge animal found in a wide variety of habitats. & \\
2. In autumn leaves fall off and most trees get (bare/bear/bair). & \\
3. A (bare/bear/bair) is food or other lure placed on a hook or in a trap and used in the \\
taking of fish, birds or other animals. \\
1. We (did/made) not go to the party yesterday. \\
2. Why do you always (did/made) the same mistake? \\
1. She doesn't have any reason to be jealous (for/about/of) me. \\
2. In Hungary, as in Italy, he was accused (of/in/with) brutality. \\
\hline
\end{tabular}

In the third exercise, it was counted that the level of lexical interference associated with the phenomenon of paronymy of the English language is $10 \%$ (2 students out of 20 students answered incorrectly) compared to the original 30\%; with the phenomenon of homonymy of the English language 5\% (1 student out of 20 answered incorrectly) compared to the original $20 \% ; 20$ students made a total of 10 errors in the second, fourth and fifth sentences, which means that the level of lexical interference associated with the "transfer" of lexical norms from one language to another is on average $11 \%$, as is the average demonstrated by students in the second and third exercises together (compared to the original 52\%). These statistics indicate a decrease in the degree of interference associated with the phenomena of paronymy and homonymy of the English language, as well as the "transfer" of norms of lexical compatibility from one language to another.

\subsubsection{Result}

Summing up the results of the test, it is worth noting that after students performed specially designed exercises to overcome lexical interference, the level of mistakes decreased from $66 \%$ to $13 \%$ in the case of "false friends of the translator"; from $52 \%$ to $11 \%$ in the case of transfer of lexical combinability norms; from $30 \%$ to $10 \%$ in the case of the phenomenon of paronymy and from 20\% to 5\%-homonymy of the English language.

Based on the data received, we concluded that it is necessary and appropriate to develop such lexical exercises that will help students reduce the level of lexical interference and minimize the number of lexical errors caused by it.

This testing also allows us to conclude that it is possible to reduce the degree of lexical interference in students, but not completely overcome it. It is possible to assume that in order to completely eliminate the interfering effect, longer work on the problem vocabulary is necessary, but even in this case, the probability of lexical errors is not excluded.

We also came to the conclusion that diaparonyms, which presented the greatest difficulty for students during the initial testing, are the most flexible class of lexes, and are easily resolved in various types of exercises when it is possible to reduce the level of interference associated with this phenomenon to a minimum. The norms of lexical combinability, which are transferred from the foreign into the native language, lead to a lot of lexical errors. This issue requires special attention.

Thus, it is necessary to emphasize that the degree of lexical interference effects among junior course students are quite high, which leads to numerous lexical errors with students; the students are more influenced by inter-language factors in the study of a foreign language, rather than intra-language.

The dynamics of the interfering influence of lexical units before and after the developed exercises performed by the students is shown in Figure 2. 


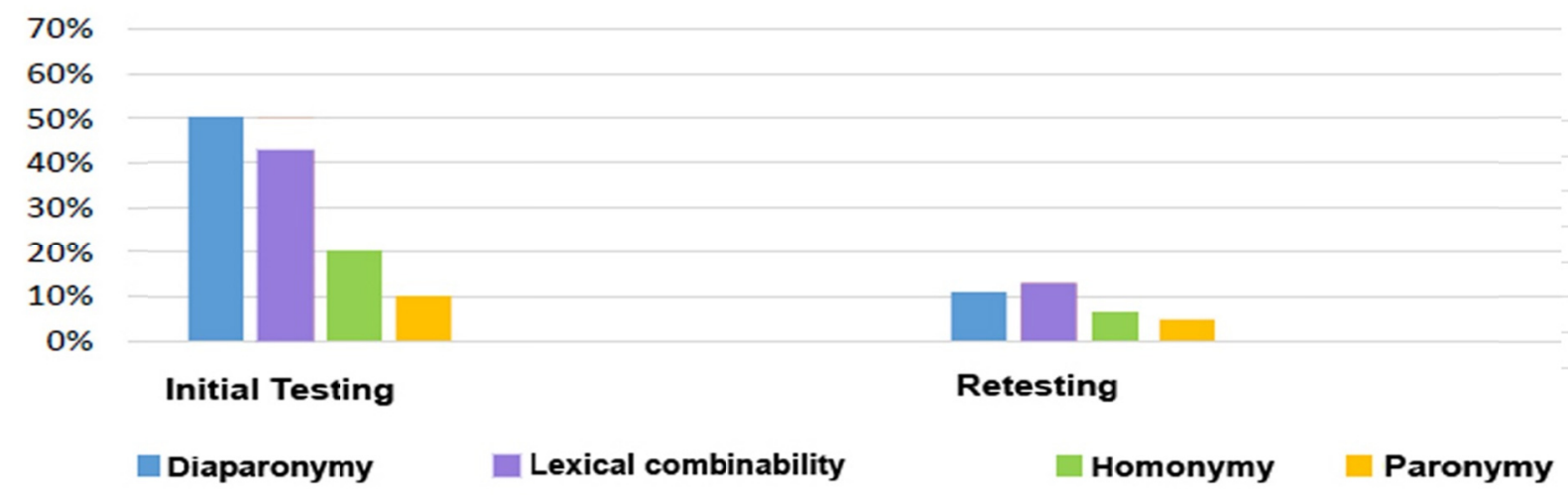

Figure 2. The level of interference before and after performing exercises by the students

In the analysis of interfering effects, it was found that the developed exercises helped to significantly minimize the level of lexical interference of the students; which resulted in a reduction of the number of lexical errors made by them during the final test in comparison with the initial one.

We also found that in order to prevent and overcome lexical interference, it is necessary to deliberately draw the attention of junior course students to potentially interfering vocabulary. Further recommendations of linguists to overcome lexical interference include compiling a list of language units from authentic sources and regular conversational practice with native speakers, viewing, reading and listening to authentic English-language material.

\section{Conclusion}

It can be concluded that factors that contribute to the appearance of intra-language and inter-language lexical interference, including the phenomena of homonymy, paronymy, diaparonymy ("false friends of the translator"), transfer of lexical norms of combinability, and word-by-word "loan-translation" of lexical units from one language to another have been analyzed by us. We also identified the features of the phenomenon of language interference in junior courses of the Azerbaijan University of Languages.

During a practical experiment, which was attended by twenty first-year students of the faculty of Education, using testing, it was found that the degree of lexical interference is quite high, which leads to numerous lexical errors of students.

This testing also helped to conclude that inter-language factors in the study of a foreign language have a greater impact on undergraduate students than intra-language ones: the degree of inter-language interference (about $75 \%$ of all erroneous responses) was much higher than intra-language interference (about $25 \%$ of all erroneous responses). We also came to the conclusion that diaparonyms or "false friends of the translator" are the most difficult for junior course students, because they are the ones which are most susceptible to interference from the Azerbaijani language; then there are the norms of lexical combinability of the English language and their "transfer" from the Azerbaijani language; the least difficulties were caused by the phenomena of paronymy and homonymy of the English language: lexical interference was low here.

At the second stage of the experiment, we developed 17 lexical exercises aimed at overcoming inter-language and intra-language lexical interference caused by various factors, including exactly those lexical units that were presented in the primary testing which were the cause of many lexical errors of junior students (all the exercises implemented one of the above-mentioned principles). These exercises were offered to the same group of twenty first-year students who passed the initial testing; $99 \%$ of students completed the exercises correctly.

At the third and final stage of work on overcoming intra-language and inter-language lexical interference in junior students, students were offered to perform exercises that were used to identify interfering effects during the initial testing. The results are mentioned in 4.2.1. Subsequently, we tracked the dynamics of interference after the students performed lexical exercises.

On the basis of the received indications, we concluded that it is effective and appropriate to develop such lexical exercises that will help students reduce the level of lexical interference and minimize the number of lexical errors caused by it. This testing also allowed us to conclude that it is possible to reduce the degree of lexical 
interference among students, but not completely overcome it.

Thus, it should be recognized that the level of lexical interference can be reduced and minimized when students perform exercises in relation to elaboration of the interfering lexical units, but such exercises should implement one of the language principles that helps to overcome the interfering influence.

It is important to note the leading role of the teacher in overcoming lexical interference of students: he/she is able to predict lexical phenomena for possible interference, drawing students' attention to them in time, preventing many lexical errors; he/she can also fix lexical errors of a specific group of students and create individual exercises aimed at overcoming lexical interference caused by certain language factors.

\section{References}

Abdygaliev, S. A. (1976). Ways to overcome lexical interference when learning a German language. Abstract of $\mathrm{PhD}$ dissertation, Moscow State pedagogical institute of foreign languages named after Maurice Thorez, Moscow. Retrieved from http://www.irbis.gnpbu.ru/Aref_1976/F0002599.pdf

Adamchik, V. V. (Ed.). (2006). The latest dictionary of foreign words and expressions. Minsk: Modern literature.

Alieva, K. V. (2012). Types of exercises to overcome lexical and semantic interference Russian speech of pupils-lacks. Modern Problems of Science and Education. Retrieved from https://www.science-education.ru/ru/article/view?id=20616

Alimov, V. V. (2017). Translation theory: Translation in the field of professional communication. Moscow: Lenand.

Collins, A. M., \& Loftus, E. F. (1975). A spreading activation theory of semantic processing. Psychological Review, 82(6), 407-428. https://doi.org/10.1037//0033-295X.82.6.407

Elgort, I. (2017). Incorrect inferences and contextual word learning in English as a second language. Journal of the European Second Language Acquisition, 1(1), 1-11. https://doi.org/10.22599/jesla.3

Hoffmann, C. (1991). An introduction to bilingualism. Applied Linguistics, 15(3), 351-354. https://doi.org/10.1093/applin/15.3.351

Hu, M., \& Nassaji, H. (2012). Ease of inferencing: Learner inferential strategies and their relationship with the retention of word meanings inferred from context. The Canadian Modern Language Review, 68(1), 54-77. https://doi.org/10.3138/cmlr.68.1.054

Kazimirova, I. S. (2013). Typical errors in the speech of students when learning several foreign languages. Journal of Russian University of Economics. Retrieved from https://pandia.ru/text/80/130/22526.php

Leontiev, A. A. (1970). Some problems of teaching Russian as a foreign language. Moscow: Moscow State University press.

Lightbown, P. M., \& Spada, N. (2013). How languages are learned (4th ed.). Oxford: Oxford University Press.

Lugovets, V. V. (2016). Methodological development: Principles of overcoming interference of the Russian language in the study of English (lexical aspect). Sankt-Petersburg.

Meara, P. (2009). Connected words: Word associations and second language vocabulary acquisition. Amsterdam: Benjamins. https://doi.org/10.1075/1ltt.24

Mezentseva, N. P. (2014). Lexical interference in English speech of Russian-speaking students. Young Scientist, 3(62), 840-844. https://moluch.ru/archive/62/9559/

Shcherbakova, M. V. (2003). Features of teaching the second foreign language to students of language faculties. VESTNIK BGU, Linguistics and Intercultural Communication Series, 2, 85-88.

Sorokina, S. S. (1971). Ways to overcome and prevent grammatical interference of syntactic subtypes in the German speech of 1st-year students of language faculties (based on the management subtype). Leningrad.

Styles, S. J. (2007). Priming and Lexical Interference in Infancy. Oxford: Oxford University Press.

Tedtoeva, Z. H. (2016). Methods for preventing and overcoming lexical and semantic interference. Retrieved from https://elibrary.ru

Weinreich, W. (1972). Monolingualism and multilingualism. In New in foreign linguistics (vol. 6, Language contacts, pp. 25-60). Retrieved from http://www.philology.ru/linguistics1/weinreich-72.htm

Wesche, M., \& Paribakht, T. S. (2009). Lexical inferencing in a first and second language: Cross-linguistic dimensions. Bristol, UK: Short Run. https://doi.org/10.21832/9781847692245 
Yanchenko, V. D. (2012). Methods of overcoming lexical interference in the speech of foreign students-non-philologists. In F. F. Farhutdinova (Ed.), Russian Language in Intercultural Communication (pp. 112-117). Proceedings of the international scientific-practical conference dedicated to the 30th anniversary of the Department of Practical Russian Language, Ivanovo State University. Moscow, Ivanovo.

Zimnya, I. A. (1989). Psychology of teaching a non-native language. Moscow: Russian language.

Zimnya, I. A. (1991). Psychology of teaching foreign languages at school. Moscow: Russian language.

\section{Copyrights}

Copyright for this article is retained by the author, with first publication rights granted to the journal.

This is an open-access article distributed under the terms and conditions of the Creative Commons Attribution license (http://creativecommons.org/licenses/by/4.0/). 